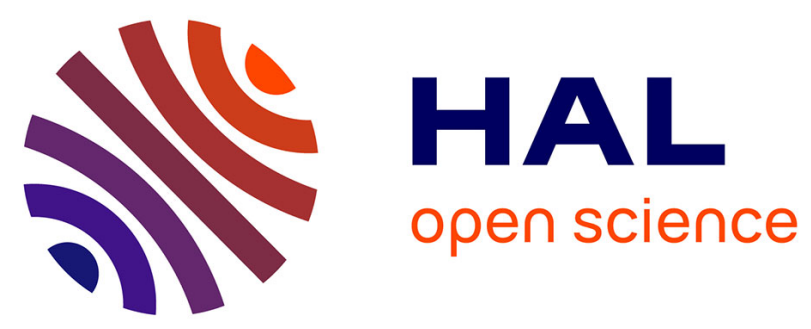

\title{
CARBANIONIC DISPLACEMENT REACTIONS AT PHOSPHORUS: DIETHYL (2-PYRIDY L)METHYLPHOSPHONATE SYNTHESIS
}

John Carran, Rachel Waschbüsch, Philippe Savignac

\section{- To cite this version:}

John Carran, Rachel Waschbüsch, Philippe Savignac. CARBANIONIC DISPLACEMENT REACTIONS AT PHOSPHORUS: DIETHYL (2-PYRIDY L)METHYLPHOSPHONATE SYNTHESIS. Phosphorus, Sulfur, and Silicon and the Related Elements, 1997, 123 (1), pp.209-218. 10.1080/10426509708044210 . hal-03166485

\section{HAL Id: hal-03166485 \\ https://hal.science/hal-03166485}

Submitted on 11 Mar 2021

HAL is a multi-disciplinary open access archive for the deposit and dissemination of scientific research documents, whether they are published or not. The documents may come from teaching and research institutions in France or abroad, or from public or private research centers.
L'archive ouverte pluridisciplinaire HAL, est destinée au dépôt et à la diffusion de documents scientifiques de niveau recherche, publiés ou non, émanant des établissements d'enseignement et de recherche français ou étrangers, des laboratoires publics ou privés. 


\title{
Carbanionic Displacement Reactions at Phosphorus : Diethyl (2-Pyridyl)methylphosphonate Synthesis*
}

\author{
John Carran, Rachel Waschbüsch and Philippe Savignac \\ Laboratoire Hétéroéléments et Coordination, URA CNRS 1499, DCPH, Ecole Polytechnique, \\ 91128 Palaiseau Cedex, France Tel. (+33) 01693345 79, Fax. (+33) 0169333990
}

We describe the formation and reactions of the $\alpha$-lithiated (2-pyridyl)methylphosphonate $\mathbf{1}$. The lithiated $\alpha$-picoline is obtained by metallation in THF at low temperature with LDA (lithium diisopropylamide) (2 equiv.). This is then condensed with diethyl chlorophosphate. The thus-formed stable carbanion 1 reacts with various electrophiles: $\mathrm{H}_{2} \mathrm{O}, \mathrm{D}_{2} \mathrm{O}$, TMSCl, $\mathrm{RX}$, and aldehydes in a Wittig-Horner reaction.

Key words: 2-picoline, LDA, diethyl chlorophosphate, Wittig-Horner reaction

\section{Introduction}

The potential value of phosphonates in both biological and industrial applications has stimulated much interest in their synthesis. Currently the formation of the carbon-phosphorus bond can be accomplished according to four main procedures. ${ }^{1}$ The first procedure, the Michaelis-Arbuzov reaction, 2 involves a trivalent phosphorus atom which is converted to a pentavalent species by displacement reactions at aliphatic carbon with a trivalent phosphorus ester. The second, the Michaelis-Becker reaction, ${ }^{3}$ involves treatment of an aliphatic carbon with a dialkyl phosphite anion. The third, the Kinnear-Perren reaction, ${ }^{4}$ involves alkylation of phosphorus halides mediated by Lewis acid, and the fourth involves the conjugate addition of trivalent phosphorus reagents at unsaturated carbon. ${ }^{5}$ In connection with our interest in phosphorylated carbanions, we have directed our attention towards a fifth process in which treatment of a pentavalent phosphorus species by an organometallic reagent is involved. This reaction, which readily generates carbon-phosphorus bonds, occurs by carbanionic displacement of halides or ester groups at a relatively electrophilic phosphorus center. ${ }^{6}$ While

* Dedicated to Dr. Robert Wolf, a pioneer of modern organophosphorous chemistry. 
there are a number of reports in the literature relating to the four previous procedures, the carbanionic displacement reactions at phosphorus are largely neglected. The synthetic value of this approach lies in the facile formation of stabilized carbanionic reagents generated by reaction of strong bases with a large variety of readily available starting materials and in the subsequent condensation reaction with trialkyl- or dialkylchlorophosphates. The method described herein involves the use of the stabilized anion of 2-methylpyridine ( $\alpha$-picoline) in reaction with diethyl chlorophosphate. Because of their use in heterocyclic chemistry, pyridines and substituted pyridines have attracted considerable attention. Pyridine derivatives, for example, are useful precursors for the preparation of polymers, pharmacological compounds, ${ }^{7}$ liquid crystals ${ }^{8}$ and ligands for transition metal cations.

\section{Results and discussion}

Diethyl (2-pyridyl)methylphosphonate $\mathbf{2}$ was first obtained by Maruszewska-Wieczorkowska, Michalski and Skowronska from 2-picolyl chloride and triethylphosphite. ${ }^{9}$ Later it was used in synthesis by Piechucki under phase-transfer catalysed Wittig-Horner reactions. ${ }^{10}$ The previously reported procedure requires the 2-picolyl chloride free-base which is known as a very unstable and expensive starting material. By contrast we have developed a convenient route to $\mathbf{2}$ in a one-pot reaction which uses easily accessible and stable starting materials: $\alpha$ picoline and diethyl chlorophosphate.

The key intermediate, 2-lithiated picolyl carbanion, was obtained at low temperature by addition of 2-methylpyridine to LDA (2 equiv.) in THF solution. On standing at low temperature we observed the appearance of a deep red-orange colour. After about $30 \mathrm{~min}$ the carbanion is condensed with diethyl chlorophosphate in an exothermic reaction. As observed by ${ }^{31} \mathrm{P}$ NMR the chlorophosphate is completely consumed and the phosphorylated carbanion $\mathbf{1}$ is stable and can be kept at $0^{\circ} \mathrm{C}$ for a long time without decomposition $\left(\delta^{31} \mathrm{P}(\mathrm{THF})+40.6\right)$. On treatment at $0^{\circ} \mathrm{C}$ with a saturated solution of $\mathrm{NH}_{4} \mathrm{Cl}$, we isolate the (2-pyridyl)methylphosphonate 2 in $83-85 \%$ yield after distillation. The preparation can be reproduced on large scale with the same success (Scheme 1).

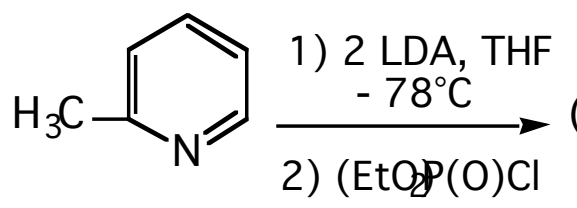

2) $(\mathrm{EtOP}(\mathrm{O}) \mathrm{Cl}$

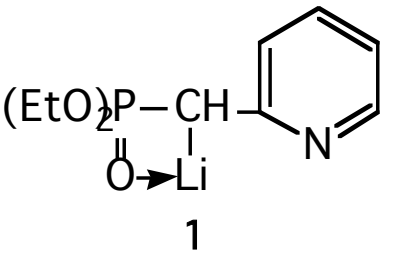

1

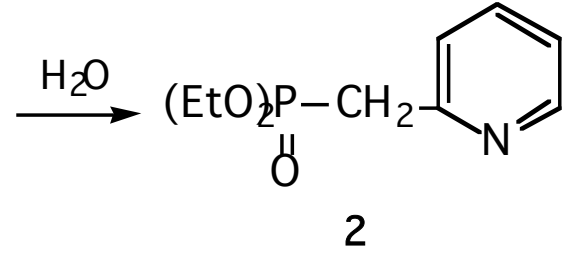

2

Scheme 1

Attempts to synthesise the 3- and 4-methylphosphonate analogues of 2 with 3-methyl and 4methyl pyridine as starting materials failed to give the expected pyridylmethylphosphonates. Phosphorylation of these compounds under the same conditions as described above resulted 
in the formation of compounds $\mathbf{3 a}$ and $\mathbf{3 b}$ respectively. The increased acidity of the ortho proton of the starting material leads to ortho lithiation and thus to a 5-methyl-2-(diethyl phosphonyl)pyridine (3a) or 4-methyl-2-(diethyl phosphonyl)pyridine (3b) product respectively. Compound 3a is only formed in low yield (20\%) and is obtained in a mixture of compounds whereas $\mathbf{3 b}$ is formed in $85 \%$ yield and is easily isolable in pure form by distillation.
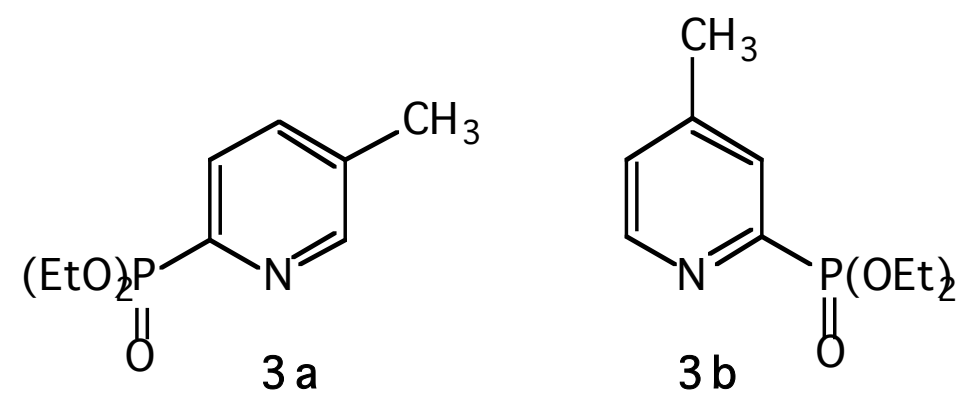

The (2-pyridyl)methylphosphonate 2 may be readily converted into the 1,1-dideuteriated compound $\mathbf{5}$ under mild basic conditions. Thus, when $\mathbf{2}$ was metallated at low temperature with LDA (2 equiv.) in THF solution followed by the exothermic condensation of TMSCl at room temperature, the $\alpha$-lithiated, $\alpha$-silylated, (2-pyridyl)methylphosphonate 4 ( $\delta^{31} \mathrm{P}$ (THF) +39.8 ) was obtained and readily converted with excess $\mathrm{D}_{2} \mathrm{O}$ at room temperature into the corresponding 1,1-dideuterio-1-(2'-pyridyl)methylphosphonate 5. We have already described a procedure for the conversion of activated methylphosphonates into alkylphosphonates via the introduction in the $\alpha$-position of a transient trimethylsilyl group. ${ }^{11}$ With activated phosphonates there is often a serious risk that the alkylphosphonate formed could undergo further alkylation. The trimethylsilyl moiety normally acts as a protecting group allowing the introduction of only one alkyl group thus avoiding the precautions needed in order to exclude the formation of dialkyl compounds resulting from acid-base equilibrium. The trimethylsilyl group is then easily removed by treatment with $\mathrm{EtOH} / \mathrm{LiOEt}$ at $0^{\circ} \mathrm{C}$. However, utilising this methodology we found that, although the desired monoalkyl product was formed, it only occured as a component of a mixture of monoalkyl-, dialkyl-, and starting product, and was thus difficult to isolate by distillation. The dialkyl compound $\mathbf{6}$ can be easily synthesised in high yield ( $85 \%$ for dimethyl) by the use of two equivalents of base in reaction with 2 . We found that for this reaction we obtained best results when one equivalent of LiHMDS (lithium hexamethyldisilazane) and one equivalent of $n$-BuLi were used together with an excess of alkylating agent. (Scheme 2) 


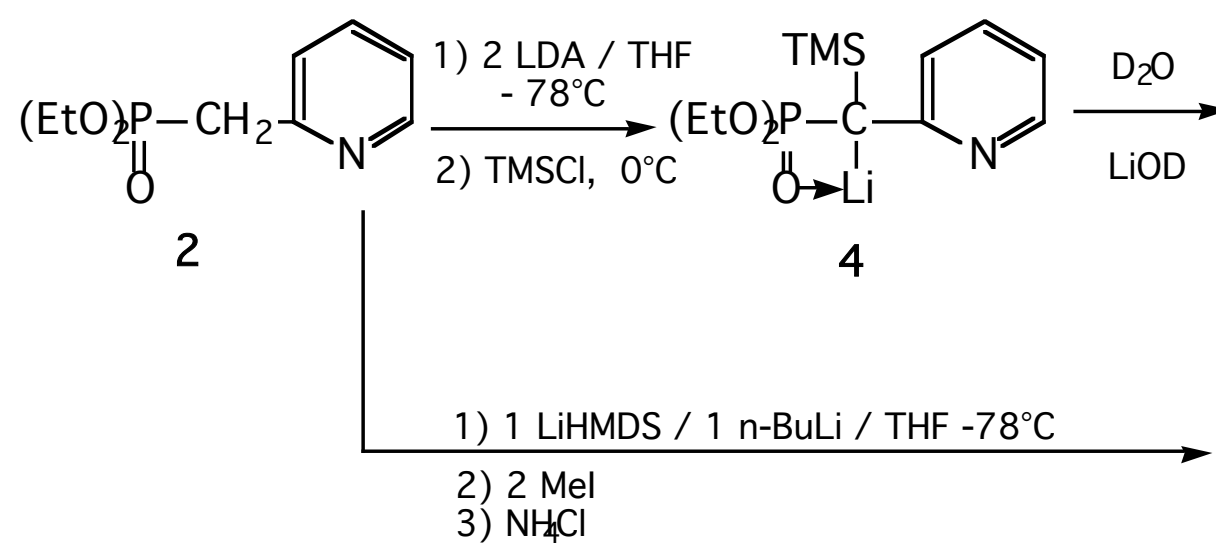

Scheme 2<smiles>[2H]C([2H])(P[R6](=O)CC)c1ccccn1</smiles>

5<smiles>CCO[P+](=O)C(C)(C)c1ccccn1</smiles>

6 a

The $\alpha$-phosphorylated carbanion $\mathbf{1}$ is ideally suited as a reagent in Wittig-Horner reactions. ${ }^{12}$ We have developed a particularly interesting and convenient one-pot procedure for converting $\alpha$-picoline into the vinylpyridine derivatives 137 in good overall yield for the two steps starting from $\alpha$-picoline without isolation of the intermediate pyridyl phosphonate 2 (Scheme 3, Table I).

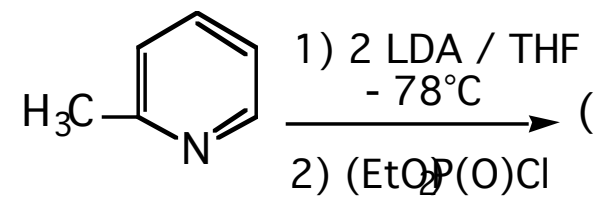

2) $(\mathrm{EtOP}(\mathrm{O}) \mathrm{Cl}$<smiles>CCO[Pb]1(O)O[AlH]C1c1ccccn1</smiles>

1

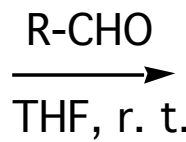

THF, r. t.<smiles>[R]C=Cc1ccccn1</smiles>

7

Scheme 3

\section{Experimental}

NMR spectra were recorded on a Bruker AC 200 spectrometer operating at $200 \mathrm{MHz}$ for proton, $50.3 \mathrm{MHz}$ for carbon and $81.01 \mathrm{MHz}$ for phosphorus. ${ }^{31} \mathrm{P}$ downfield shifts $(\delta)$ are expressed with a positive sign, in ppm, relative to external $85 \% \mathrm{H}_{3} \mathrm{PO}_{4}$ in $\mathrm{H}_{2} \mathrm{O}$. ${ }^{1} \mathrm{H}$ and ${ }^{13} \mathrm{C}$ chemical shifts $(\delta)$ are reported in ppm relative to $\mathrm{CDCl}_{3}$ as internal standard. Coupling constants $(J)$ are given in Hz. The following abbreviations are used: s, d, t, q, m for singlet, doublet, triplet, quadruplet and multiplet respectively. Organic solvents were purified by standard procedures. THF was distilled under an inert atmosphere from purple solutions of sodium:benzophenone ketyl. The synthesis of all compounds were carried out under dry nitrogen. 
Table I

\begin{tabular}{|c|c|c|}
\hline Product 7 & Yield (\%) \\
\hline c & 62 \\
\hline c & \\
\hline d & \\
\hline
\end{tabular}

\section{Diethyl (2-Pyridyl)methylphosphonate 2}

To a solution of $n$-BuLi (66 ml of a $1.59 \mathrm{M}$ soln. in hexane; $0.105 \mathrm{~mol}$ ) in THF (100 ml) at $20^{\circ} \mathrm{C}$ is added diisopropylamine $(11.6 \mathrm{~g} ; 0.116 \mathrm{~mol})$ dropwise. This solution is stirred for 10 min and then cooled to $-78^{\circ} \mathrm{C}$. A mixture of $\alpha$-picoline $(4.65 \mathrm{~g} ; 50 \mathrm{mmol})$ in THF $(10 \mathrm{ml})$ is then added dropwise to the freshly prepared LDA. A red-orange colour is observed. The reaction mixture is stirred at $-78^{\circ} \mathrm{C}$ for $30 \mathrm{~min}$ before a solution of diethyl chlorophosphate (9.50 g; $55 \mathrm{mmol})$ in THF (15 ml) is slowly added via a dropping funnel. The mixture is stirred at $-78^{\circ} \mathrm{C}$ for $10 \mathrm{~min}$ and then slowly allowed to warm to room temperature. A solution of $\mathrm{NH}_{4} \mathrm{Cl}$ in water $(30 \mathrm{ml})$ is then added to the reaction mixture and the phases are separated after stirring for $10 \mathrm{~min}$. The aqueous phase is then extracted with dichloromethane $(3 \times 50$ $\mathrm{ml}$ ) and the combined organic phases are dried over $\mathrm{MgSO}_{4}$ prior to evaporation and distillation by bulb-to-bulb apparatus to yield the title compound as a yellow oil $(9.7 \mathrm{~g}, 85 \%$, bp $240-250^{\circ} \mathrm{C} / 20 \mathrm{mmHg}$ ). 
${ }^{31} \mathrm{P}-\mathrm{NMR}\left(\mathrm{CDCl}_{3}\right): \delta=24.9 .{ }^{1} \mathrm{H}-\mathrm{NMR}\left(\mathrm{CDCl}_{3}\right): \delta=1.20-1.27\left(\mathrm{~m}, 6 \mathrm{H}, \mathrm{OCH}_{2} \mathrm{CH}_{3}\right), 3.38(\mathrm{~d}$, $\left.2 \mathrm{H},{ }^{2} \mathrm{~J} \mathrm{PH}=22, \mathrm{PCH}_{2}\right), 3.98-4.12\left(\mathrm{~m}, 4 \mathrm{H}, \mathrm{OCH}_{2}\right), 7.15-7.18(\mathrm{~m}, 1 \mathrm{H}$, pyr-H), $7.34-7.38(\mathrm{~m}$, $1 \mathrm{H}, \quad$ pyr-H), $7.58-7.62(\mathrm{~m}, 1 \mathrm{H}, \quad$ pyr-H$), \quad 8.50-8.53 \quad(\mathrm{~m}, \quad 1 \mathrm{H}, \quad$ pyr-H $) . \quad{ }^{13} \mathrm{C}-\mathrm{NMR}$ $\left(\mathrm{CDCl}_{3}\right)(\mathrm{JMOD}): \delta=15.72\left(\mathrm{OCH}_{2} \underline{\mathrm{CH}}_{3}\right), 34.61\left(\mathrm{~d},{ }^{1} \mathrm{~J}_{\mathrm{PC}}=135, \mathrm{PCH}_{2}\right), 61.42\left(\mathrm{OCH}_{2}\right), 121.30$ (pyr-CH), 123.69 (pyr-CH), 135.75 (pyr-CH), 148.77 (pyr-CH), 152.18 (pyr-C).

\section{4-methyl-2-(diethylphosphonyl)pyridine 3b}

To freshly prepared LDA (from $15.15 \mathrm{~g}(0.15 \mathrm{~mol})$ diisopropylamine and $66.6 \mathrm{ml}$ of BuLi) in THF $(50 \mathrm{ml})$ at $-78^{\circ} \mathrm{C}$ is added a solution of 4-picoline $(4.65 \mathrm{~g}, 50 \mathrm{mmol})$ in THF $(10 \mathrm{ml})$. The resulting yellow solution is stirred at $-78^{\circ} \mathrm{C}$ for ten minutes and then allowed to slowly warm to $0^{\circ} \mathrm{C}$ over a period of $1 \mathrm{~h}$. The reaction mixture is then recooled to $-78^{\circ} \mathrm{C}$ and a solution of diethyl chlorophosphate $(9.5 \mathrm{~g}, 55 \mathrm{mmol}))$ in THF $(10 \mathrm{ml})$ is added. An exothermic reaction is observed and the reaction mixture is allowed to slowly warm and is stirred for $1 \mathrm{~h}$ at room temperature. A saturated solution of ammonium chloride $(50 \mathrm{ml})$ is added to the reaction mixture and the phases are then separated. The aqueous phase is first washed with diethyl ether $(3 \times 20 \mathrm{ml})$ and then dichloromethane $(1 \times 20 \mathrm{ml})$. The combined organic extracts are dried over $\mathrm{MgSO}_{4}$ and are then filtered and solvents are evaporated. The resulting orange liquid is then distilled to give the title product as a mobile yellow oil (bp 175$\left.185^{\circ} \mathrm{C} / 0.1 \mathrm{~mm} / \mathrm{Hg} ; 9.7 \mathrm{~g}, 85 \%\right)$.

31P-NMR $\left(\mathrm{CDCl}_{3}\right): \delta=+11.62 .{ }^{1} \mathrm{H}-\mathrm{NMR}\left(\mathrm{CDCl}_{3}\right): \delta=1.25\left(\mathrm{t}, 6 \mathrm{H}, J=7.1, \mathrm{OCH}_{2} \underline{\mathrm{CH}}_{3}\right), 2.31$ (s, 3H, Pyr- $\left.\mathrm{CH}_{3}\right), 4.02-4.22\left(\mathrm{~m}, 4 \mathrm{H}, \mathrm{OCH}_{2}\right), 7.14-7.17(\mathrm{~m}, 1 \mathrm{H}, \mathrm{pyr}-\mathrm{H}), 7.71-7.75(\mathrm{~m}, 1 \mathrm{H}$, pyr-H), $8.54(\mathrm{~d}, 1 \mathrm{H}, J=4.9, \mathrm{pyr}-\mathrm{H}) .{ }^{13} \mathrm{C}-\mathrm{NMR}\left(\mathrm{CDCl}_{3}\right)(\mathrm{JMOD}): \delta=15.82\left(\mathrm{OCH}_{2} \underline{\mathrm{CH}}_{3}\right)$, $20.18\left(\right.$ pyr- $\left.\mathrm{CH}_{3}\right), 62.32\left(\mathrm{OCH}_{2}\right), 126.15$ (pyr-CH), 128.55 (d, J=25.7, pyr-CH), 116.9 (d, $\mathrm{J}=22.5$, pyr-C), 149.87 (d, J=24.1, pyr-CH).

\section{Diethyl 1,1-dideuterio-1-(2'-pyridyl)methylphosphonate 5}

The same procedure as above is employed except that after addition of diethyl chlorophosphate the reaction mixture is warmed to room temperature and then a solution of TMSCl (1.1 equiv.) is added, the reaction is exothermic and the reaction mixture is then stirred at $20^{\circ} \mathrm{C}$. After $30 \mathrm{~min}, \mathrm{D}_{2} \mathrm{O}(30 \mathrm{ml})$ is added at room temperature with vigorous stirring of the mixture. When deuteriolysis is complete $(60 \mathrm{~min})$ the reaction mixture is treated with an aqueous solution of $\mathrm{NH}_{4} \mathrm{Cl}$. The aqueous phase is extracted with $\mathrm{CH}_{2} \mathrm{Cl}_{2}(3 \mathrm{x}$ $50 \mathrm{ml})$, the organic layer is dried $\left(\mathrm{MgSO}_{4}\right)$ and the solvents are evaporated off under reduced pressure. The crude product is then purified by bulb-to-bulb distillation to yield compound $\mathbf{5}$ as a yellow oil. $\left(9.6 \mathrm{~g}, 83 \%\right.$, b.p. $\left.230-240^{\circ} \mathrm{C} / 20 \mathrm{mmHg}\right)$.

${ }^{31} \mathrm{P}-\mathrm{NMR}\left(\mathrm{CDCl}_{3}\right): \delta=25.4 .{ }^{1} \mathrm{H}-\mathrm{NMR}\left(\mathrm{CDCl}_{3}\right): \delta=1.20-1.27\left(\mathrm{~m}, 6 \mathrm{H}, \mathrm{OCH}_{2} \mathrm{CH}_{3}\right), 4.0-4.18$ $\left(\mathrm{m}, 4 \mathrm{H}, \mathrm{OCH}_{2}\right), 7.15-7.21(\mathrm{~m}, 1 \mathrm{H}$, pyr-H) $, 7.36-7.41(\mathrm{~m}, 1 \mathrm{H}, \mathrm{pyr}-\mathrm{H}), 7.6-7.68(\mathrm{~m}, 1 \mathrm{H}$, pyr$\mathrm{H}), 8.52-8.57(\mathrm{~m}, 1 \mathrm{H}, \mathrm{pyr}-\mathrm{H}) .{ }^{13} \mathrm{C}-\mathrm{NMR}\left(\mathrm{CDCl}_{3}\right)(\mathrm{JMOD}): \delta=15.79\left(\mathrm{OCH}_{2} \mathrm{CH}_{3}\right), 35.8(\mathrm{~d}$, 
$\left.{ }^{1} J_{\mathrm{PC}}=135, \mathrm{PCD}_{2}\right), 61.76\left(\mathrm{OCH}_{2}\right), 121.56(\mathrm{pyr}-\mathrm{CH}), 123.82(\mathrm{pyr}-\mathrm{CH}), 136.22(\mathrm{pyr}-\mathrm{CH})$, 148.81 (pyr-CH), 152.10 (pyr-C).

\section{Diethyl 1-methyl-1-(2'-pyridyl)ethylphosphonate 6a}

LiHMDS $(4.4 \mathrm{mmol})$ is prepared at $-78^{\circ} \mathrm{C}$ by the addition of a solution of HMDS $(0.78 \mathrm{~g}, 1.1$ equiv.) in THF $(5 \mathrm{ml})$ to a solution of $\mathrm{n}-\mathrm{BuLi}(3.03 \mathrm{ml}$ of a $1.45 \mathrm{M}$ soln, $4.4 \mathrm{mmol})$ in THF (20 $\mathrm{ml})$ at $-78^{\circ} \mathrm{C}$. After $20 \mathrm{~min}$ a solution of diethyl (2-Pyridyl)methylphosphonate $2(1 \mathrm{~g}, 4.4$ $\mathrm{mmol})$ in THF $(10 \mathrm{ml})$ is added to the reaction mixture at $-78^{\circ} \mathrm{C}$. The now yellow solution is allowed to slowly warm to RT. The reaction mixture is then cooled to $-78^{\circ} \mathrm{C}$ and $n$ - $\mathrm{BuLi}$ ( $3.03 \mathrm{ml}, 4.4 \mathrm{mmol})$ is added. The reaction mixture is cooled to $-50^{\circ} \mathrm{C}$ and $\mathrm{MeI}(1.25 \mathrm{~g}, 2.2$ equiv) in THF ( $5 \mathrm{ml}$ ) is slowly added. The mixture is allowed to slowly warm to RT during which time the yellow colour disappears. $\mathrm{NH}_{4} \mathrm{Cl}(20 \mathrm{ml})$ is slowly added to the reaction mixture and the phases are separated. The aqueous phase is washed with diethyl ether $(3 \mathrm{x} 10$ $\mathrm{ml}$ ) and the combined organic extracts are dried over $\mathrm{MgSO}_{4}$ filtered and evaporated to yield a yellow oil which on distillation gives the title compound as a clear colourless liquid $(0.91 \mathrm{~g}$, $85 \%$, b. p. $\left.150^{\circ} \mathrm{C} / 0.4 \mathrm{~mm} \mathrm{Hg}\right)$.

${ }^{31} \mathrm{P}-\mathrm{NMR}\left(\mathrm{CDCl}_{3}\right): \delta=31.6 .{ }^{1} \mathrm{H}-\mathrm{NMR}\left(\mathrm{CDCl}_{3}\right): \delta=1.17\left(\mathrm{t}, 6 \mathrm{H},{ }^{3} \mathrm{JHH}_{\mathrm{HH}}=7.2, \mathrm{OCH}_{2} \mathrm{CH}_{3}\right), 1.63$ $\left(\mathrm{d}, 6 \mathrm{H},{ }^{3} J_{\mathrm{PH}}=16.6, \mathrm{PCMe}_{2}\right), 3.8-4.02\left(\mathrm{~m}, 4 \mathrm{H}, \mathrm{OCH}_{2}\right), 7.05-7.15(\mathrm{~m}, 1 \mathrm{H}, \mathrm{pyr}-\mathrm{H}), 7.58-7.64$ $\left(\mathrm{m}, 2 \mathrm{H}\right.$, pyr-H), 8.52-8.57 (m, 1H, pyr-H). ${ }^{13} \mathrm{C}-\mathrm{NMR}\left(\mathrm{CDCl}_{3}\right)(\mathrm{JMOD}): \delta=15.6$ $\left(\mathrm{OCH}_{2} \underline{\mathrm{CH}}_{3}\right), 20.27$ (pyr- $\left.\mathrm{CH}_{3}\right), 62.11\left(\mathrm{OCH}_{2}\right), 126.26$ (pyr-CH), 128.39 (d, J=25, pyr-CH), 146.85 (d, $J=13$, pyr-C), 149.6 (d, $J=19$, pyr-CH), 151.15 (d, $J=177$, pyr-C).

\section{General Synthesis of Pyridylethenes 7a-e}

LDA $(11 \mathrm{mmol})$ is formed as before and cooled to $-78^{\circ} \mathrm{C}$. $\alpha$-Picoline $(0.49 \mathrm{~g}, 5.2 \mathrm{mmol})$ in THF $(10 \mathrm{ml})$ is added dropwise maintaining the temperature at $-78^{\circ} \mathrm{C}$, the solution is stirred for $30 \mathrm{~min}$ at this temperature. Diethyl chlorophosphate $(0.98 \mathrm{~g}, 5.5 \mathrm{mmol})$ in THF $(10 \mathrm{ml})$ is then added dropwise at $-78^{\circ} \mathrm{C}$, the reaction is stirred for $10 \mathrm{~min}$ and then allowed to warm to room temperature. A solution of aldehyde $(5 \mathrm{mmol})$ in THF $(10 \mathrm{ml})$ is then added at this temperature. After 10 min. stirring, $\mathrm{H}_{2} \mathrm{O}(20 \mathrm{ml})$ is added. The phases were separated and the aqueous phase extracted with diethyl ether $(3 \times 20 \mathrm{ml})$. The combined organic phases were dried over $\mathrm{MgSO}_{4}$ and the solvents evaporated. Distillation by bulb-to-bulb apparatus yields the pyridylethenes $7 \mathbf{a}-\mathbf{e}$ (see yields in Table 1).

\section{1,2-bis(2'-pyridyl)ethene (E) 7a}

b.p. $210-215^{\circ} \mathrm{C} / 0.2 \mathrm{mmHg}$.

${ }^{1} \mathrm{H}-\mathrm{NMR}\left(\mathrm{CDCl}_{3}\right): \delta=7.17\left(\mathrm{ddd}, 2 \mathrm{H},{ }^{3} J_{\mathrm{HH}}=7.5,4.8,{ }^{4} J_{\mathrm{HH}}=1.2, \mathrm{pyr}-\mathrm{H}^{5}\right), 7.41(\mathrm{dt}, 2 \mathrm{H}$, $\left.{ }^{3} J_{\mathrm{HH}}=7.8,{ }^{4} J_{\mathrm{HH}}=1.0, \mathrm{pyr}-\mathrm{H}^{3}\right), 7.67\left(\mathrm{td}, 2 \mathrm{H},{ }^{3} J_{\mathrm{HH}}=7.7,{ }^{4} J_{\mathrm{HH}}=1.8\right.$, pyr- $\left.\mathrm{H}^{4}\right), 7.69\left(\mathrm{~s}, 2 \mathrm{H}, \mathrm{H}^{1}\right.$, $\left.\mathrm{H}^{2}\right), 8.62\left(\mathrm{ddd}, 2 \mathrm{H},{ }^{3} J_{\mathrm{HH}}=4.8,{ }^{4} J_{\mathrm{HH}}=1.8,0.9\right.$, pyr- $\left.\mathrm{H}^{6}\right) .{ }^{13} \mathrm{C}-\mathrm{NMR}\left(\mathrm{CDCl}_{3}\right): \delta=123.3(\mathrm{~s}$, 


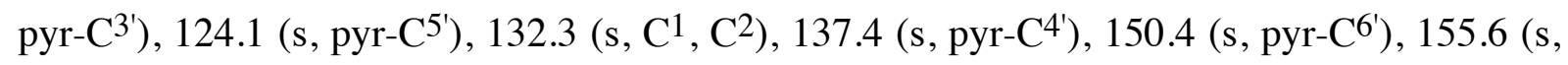
pyr-C $\left.2^{\prime}\right) . \mathrm{m} / \mathrm{z}$ (EI) $182\left(\mathrm{M}^{+}, 31 \%\right), 181$ (100), 179 (2), 154 (8).

\section{(2'-pyridyl)-2-(4'-methylphenyl)ethene (E) 7b}

b.p. $195-200^{\circ} \mathrm{C} / 0.2 \mathrm{mmHg}$.

${ }^{1} \mathrm{H}-\mathrm{NMR}\left(\mathrm{CDCl}_{3}\right): \delta=2.37\left(\mathrm{~s}, 3 \mathrm{H}, \mathrm{CH}_{3}\right), 7.11\left(\mathrm{ddd}, 1 \mathrm{H},{ }^{3} J_{\mathrm{HH}}=7.5,2.6,{ }^{4} J_{\mathrm{HH}}=1.2, \mathrm{pyr}-\mathrm{H}^{5}\right)$, $7.13\left(\mathrm{~d}, 1 \mathrm{H},{ }^{3} J_{\mathrm{HH}}=16.0, \mathrm{H}^{2}\right), 7.18\left(\mathrm{~d}, 2 \mathrm{H},{ }^{3} J_{\mathrm{HH}}=8.8, \mathrm{Ar}-\mathrm{H}\right), 7.37\left(\mathrm{dt}, 1 \mathrm{H},{ }^{3} J_{\mathrm{HH}}=7.9,{ }^{4} J_{\mathrm{HH}}=\right.$ 0.9 , pyr- $\left.\mathrm{H}^{3}\right), 7.48\left(\mathrm{~d}, 2 \mathrm{H},{ }^{3} J_{\mathrm{HH}}=8.8, \mathrm{Ar}-\mathrm{H}\right), 7.61\left(\mathrm{~d}, 1 \mathrm{H},{ }^{3} J_{\mathrm{HH}}=16.0, \mathrm{H}^{1}\right), 7.65(\mathrm{td}, 1 \mathrm{H}$, ${ }^{3} J_{\mathrm{HH}}=7.7,{ }^{4} J_{\mathrm{HH}}=1.8$, pyr-H $\left.{ }^{4}\right), 8.60\left(\mathrm{ddd}, 1 \mathrm{H},{ }^{3} J_{\mathrm{HH}}=4.8,{ }^{4} J_{\mathrm{HH}}=1.7,0.8\right.$, pyr- $\left.\mathrm{H}^{6}\right) .{ }^{13} \mathrm{C}-$ NMR $\left(\mathrm{CDCl}_{3}\right): \delta=21.8\left(\mathrm{~s}, \mathrm{CH}_{3}\right), 122.4\left(\mathrm{~s}_{\text {broad }}, \mathrm{pyr}-\mathrm{C}^{3}, \mathrm{C}^{5}\right), 127.1\left(\mathrm{~s}, \mathrm{C}^{2}\right), 127.6(\mathrm{~s}, \mathrm{Ar})$, 129.9 (s, Ar), 132.3 (s, $\left.\mathrm{C}^{1}\right), 134.2$ (s, Ar), 137.2 (s, pyr- $\mathrm{C}^{4}$ ), 138.9 (s, Ar), 149.8 (s, pyr- $\mathrm{C}^{6}$ ), 156.1 (s, pyr-C $\left.2^{\prime}\right) . \mathrm{m} / \mathrm{z}(\mathrm{EI}) 195\left(\mathrm{M}^{+}, 25 \%\right), 194$ (100), 179 (4).

\section{(2'-pyridyl)-2-(4'-methoxyphenyl)ethene (E) 7c}

b.p. $245-250^{\circ} \mathrm{C} / 1 \mathrm{mmHg}$.

${ }^{1} \mathrm{H}-\mathrm{NMR}\left(\mathrm{CDCl}_{3}\right): \delta=3.83\left(\mathrm{~s}, 3 \mathrm{H}, \mathrm{OCH}_{3}\right), 6.91\left(\mathrm{~d}, 2 \mathrm{H},{ }^{3} J_{\mathrm{HH}}=8.8, \mathrm{Ar}-\mathrm{H}\right), 7.05(\mathrm{~d}, 1 \mathrm{H}$, $\left.{ }^{3} J_{\mathrm{HH}}=16.0, \mathrm{H}^{2}\right), 7.14\left(\mathrm{ddd}, 1 \mathrm{H},{ }^{3} J_{\mathrm{HH}}=7.4,2.6,{ }^{4} J_{\mathrm{HH}}=1.1, \mathrm{pyr}-\mathrm{H}^{5}\right), 7.37\left(\mathrm{dt}, 1 \mathrm{H},{ }^{3} J_{\mathrm{HH}}=7.9\right.$, ${ }^{4} J_{\mathrm{HH}}=0.9$, pyr- $\left.{ }^{3}\right), 7.53\left(\mathrm{~d}, 2 \mathrm{H},{ }^{3} J_{\mathrm{HH}}=8.8, \mathrm{Ar}-\mathrm{H}\right), 7.59\left(\mathrm{~d}, 1 \mathrm{H},{ }^{3} J_{\mathrm{HH}}=16.0, \mathrm{H}^{1}\right), 7.67(\mathrm{td}$, $\left.1 \mathrm{H},{ }^{3} J_{\mathrm{HH}}=7.7,{ }^{4} J_{\mathrm{HH}}=1.8, \mathrm{pyr}-\mathrm{H}^{4^{\prime}}\right), 8.59\left(\mathrm{ddd}, 1 \mathrm{H},{ }^{3} J_{\mathrm{HH}}=4.8,{ }^{4} J_{\mathrm{HH}}=1.7,0.8\right.$, pyr- $\left.\mathrm{H}^{6}\right) .{ }^{13} \mathrm{C}-$ $\mathrm{NMR}\left(\mathrm{CDCl}_{3}\right): \delta=55.9\left(\mathrm{~s}, \mathrm{OCH}_{3}\right), 114.8(\mathrm{~s}, \mathrm{Ar}), 122.3\left(\mathrm{~s}, \mathrm{pyr}-\mathrm{C}^{3}\right), 122.4\left(\mathrm{~s}, \mathrm{pyr}-\mathrm{C}^{5}\right), 126.2$ (s, $\left.\mathrm{C}^{2}\right), 129.1$ (s, Ar), 130.0 (s, Ar), $133.1\left(\mathrm{~s}, \mathrm{C}^{1}\right), 137.3$ (s, pyr-C $\left.{ }^{4}\right), 150.0$ (s, pyr-C $\left.6^{6}\right), 156.4$ (s, pyr-C $\left.2^{\prime}\right), 160.5$ (s, Ar). m/z (EI) $211\left(\mathrm{M}^{+}, 37 \%\right), 210$ (100), 195 (14), 167 (34).

\section{(2'-pyridyl)-2-(3',4'-dioxymethylenephenyl)ethene (E) 7d}

b.p. $235^{\circ} \mathrm{C} / 0.1 \mathrm{mmHg}$.

${ }^{1} \mathrm{H}-\mathrm{NMR}\left(\mathrm{CDCl}_{3}\right): \delta=5.99\left(\mathrm{~s}, 2 \mathrm{H}, \mathrm{OCH}_{2} \mathrm{O}\right), 6.81\left(\mathrm{~d}, 2 \mathrm{H},{ }^{3} J_{\mathrm{HH}}=8.0, \mathrm{Ar}\right), 7.01\left(\mathrm{~d}, 1 \mathrm{H},{ }^{3} J_{\mathrm{HH}}=\right.$ $\left.16.1, \mathrm{H}^{2}\right), 7.03\left(\mathrm{dd}, 1 \mathrm{H},{ }^{3} J_{\mathrm{HH}}=8.0,{ }^{4} J_{\mathrm{HH}}=1.7, \mathrm{Ar}\right), 7.13\left(\mathrm{~d}, 1 \mathrm{H},{ }^{4} J_{\mathrm{HH}}=1.7, \mathrm{Ar}\right), 7.14(\mathrm{ddd}$, $\left.1 \mathrm{H},{ }^{3} J_{\mathrm{HH}}=7.4,4.9,{ }^{4} J_{\mathrm{HH}}=1.0, \mathrm{pyr}-\mathrm{H}^{5}\right), 7.36\left(\mathrm{~d}, 1 \mathrm{H},{ }^{3} J_{\mathrm{HH}}=8.0, \mathrm{pyr}-\mathrm{H}^{3}\right), 7.57\left(\mathrm{~d}, 1 \mathrm{H},{ }^{3} J_{\mathrm{HH}}=\right.$ $\left.16.1, \mathrm{H}^{1}\right), 7.67\left(\mathrm{td}, 1 \mathrm{H},{ }^{3} J_{\mathrm{HH}}=7.7,{ }^{4} J_{\mathrm{HH}}=1.8\right.$, pyr- $\left.\mathrm{H}^{4}\right), 8.58\left(\mathrm{dm}, 1 \mathrm{H},{ }^{3} J_{\mathrm{HH}}=4.9\right.$, pyr- $\left.\mathrm{H}^{6}\right)$. ${ }^{13} \mathrm{C}-\mathrm{NMR}\left(\mathrm{CDCl}_{3}\right): \delta=101.8\left(\mathrm{~s}, \mathrm{OCH}_{2} \mathrm{O}\right), 106.4(\mathrm{~s}, \mathrm{Ar}), 109.0\left(\mathrm{~s}, \mathrm{C}^{2} \mathrm{Ar}\right), 122.4\left(\mathrm{~s}, \mathrm{pyr}^{\prime} \mathrm{C}^{3}\right)$, 122.5 (s, pyr- $\mathrm{C}^{5}$ ), 123.1 (s, Ar), 126.4 (s, $\left.\mathrm{C}^{2}\right), 131.6$ (s, Ar), 133.1 (s, $\left.\mathrm{C}^{1}\right), 137.2$ (s, pyr- $\left.\mathrm{C}^{4}\right)$, 148.5 (s, Ar), 148.7 (s, Ar), 149.9 (s, pyr- $\left.\mathrm{C}^{6}\right), 156.1$ (s, pyr- $\left.\mathrm{C}^{2}\right)$.

\section{(2'-pyridyl)-2-(2'-thiophenyl)ethene (E) 7e}

b.p. $180-185^{\circ} \mathrm{C} / 1 \mathrm{mmHg}$.

${ }^{1} \mathrm{H}-\mathrm{NMR}\left(\mathrm{CDCl}_{3}\right): \delta=6.94\left(\mathrm{~d}, 1 \mathrm{H},{ }^{3} J_{\mathrm{HH}}=15.8, \mathrm{H}^{2}\right), 6.91\left(\mathrm{dd}, 1 \mathrm{H},{ }^{3} J_{\mathrm{HH}}=5.1,3.6\right.$, thioph$\left.\mathrm{H}^{4}\right), 7.11\left(\mathrm{ddm}, 1 \mathrm{H},{ }^{3} J_{\mathrm{HH}}=7.5,4.8, \mathrm{pyr}^{\prime} \mathrm{H}^{5}\right), 7.14\left(\mathrm{~d}, 1 \mathrm{H},{ }^{3} J_{\mathrm{HH}}=3.6\right.$, thioph- $\left.\mathrm{H}^{3}\right), 7.23(\mathrm{~d}$, $1 \mathrm{H},{ }^{3} J_{\mathrm{HH}}=5.1$, thioph- $\left.\mathrm{H}^{5}\right), 7.29\left(\mathrm{~d}, 1 \mathrm{H},{ }^{3} J_{\mathrm{HH}}=7.5, \mathrm{pyr}-\mathrm{H}^{3}\right), 7.62\left(\mathrm{td}, 1 \mathrm{H},{ }^{3} J_{\mathrm{HH}}=7.5,{ }^{4} J_{\mathrm{HH}}=\right.$ 1.8, pyr- $\left.\mathrm{H}^{4}\right), 7.76\left(\mathrm{~d}, 1 \mathrm{H},{ }^{3} J_{\mathrm{HH}}=15.8, \mathrm{H}^{1}\right), 8.56\left(\mathrm{dm}, 1 \mathrm{H},{ }^{3} J_{\mathrm{HH}}=4.8\right.$, pyr- $\left.\mathrm{H}^{6}\right) .{ }^{13} \mathrm{C}-\mathrm{NMR}$ 
$\left(\mathrm{CDCl}_{3}\right): \delta=122.6\left(\mathrm{~s}\right.$, pyr-C $\left.\mathrm{C}^{3}\right), 122.8\left(\mathrm{~s}\right.$, pyr- $\left.\mathrm{C}^{5^{\prime}}\right), 126.1$ (s, thioph- $\left.\mathrm{C}^{3}\right), 126.3\left(\mathrm{~s}\right.$, thioph- $\left.\mathrm{C}^{4}\right)$, 127.8 (s, thioph- $\left.\mathrm{C}^{5}\right), 128.4\left(\mathrm{~s}, \mathrm{C}^{1}, \mathrm{C}^{2}\right), 137.2\left(\mathrm{~s}\right.$, pyr- $\left.\mathrm{C}^{4}\right), 142.8\left(\mathrm{~s}\right.$, thioph- $\left.\mathrm{C}^{2}\right), 150.3$ (s, pyr$\left.\mathrm{C}^{6}\right), 155.8$ (s, pyr-C $\left.2^{\prime}\right) . \mathrm{m} / \mathrm{z}(\mathrm{EI}) 187\left(\mathrm{M}^{+}, 28 \%\right), 186$ (100), 154 (10).

\section{Acknowledgements}

We thank the CNRS for grants for J. C. and R. W.. We are also grateful to Mr. M. Levard (URA CNRS 1307) of the Ecole Polytechnique for the mass spectra.

\section{References}

1 R. Engel, Synthesis of Carbon-Phosphorus bonds, CRC press, Boca Raton, FL, (1988).

2 A. Michaelis, R. Kaehne, Ber, 31, 1048, (1893).

A. E. Arbusov, J. Russ. Phys. Chem. Soc., 38, 687, (1906).

3 A. Michaelis, T. Becker, Chem. Ber., 30, 1003, (1897).

4 A. M. Kinnear, E. A. Perren, J. Chem. Soc., 3, 3437, (1952).

5 A. N. Pudovic, I. V. Konovalova, Synthesis, 81, (1979).

6 R. Engel, Synthesis of Carbon-Phosphorus bonds, CRC press, Boca Raton, FL, (1988), Chapter 5, p 168.

7 A. Kleeman, Chem. Ztg., 101, 389, (1977).

H. Beschke, A. Kleeman, et al, Ullmans Encyclopädie der technischen Chemie; Verlag Chemie, Weinheim, Deerfireld Beach, Florida, Bd. 19, 592-617 (1980).

8 J. Barbera, E. Melendz, P. Romero, J. L. Serrano, Mol. Cryst. Liq. Cryst., 126, 259, (1985).

K. Seto, H. Shimojitosyo, H. Matsubara, S. Takahashi, Chem. Lett., 323 (1990).

9 E. Maruszewska-Wieczorkowska, J. Michalski, A. Skowronska, Rocz. Chem., 30, 1197, (1957).

10 C. Piecucki, Synthesis, 869, (1974). ibid Synthesis, 187,(1976).

11 M.-P. Teulade, P. Savignac, J. Organomet. Chem., 338, 295, (1988).

12 A. W. Johnson, W. C. Kaska, K. A. Ostoja, D. A. Dixon, Ylides and Imines of Phosphorus, Wiley, New-York, (1993).

13 P-M., Windsceif, F. Vögtle, Synthesis, 87, (1994).

K. Kondo, N. Ohnishi, K. Takemoto, H. Yoshida, K. Yoshida, J. Org. Chem., 57, 1622, (1992). 